\title{
NIGERIA'S FEDERALISM AND CHALLENGES OF IMPLEMENTING FEDERAL CHARACTER PRINCIPLE
}

https://doi.org/10.47743/jopafl-2021-19-04

\author{
Olu OKOTONI \\ Department of Public Administration, Obafemi Awolowo University, Ile-Ife, Nigeria
}

\author{
Adeleke ADEGBAMI \\ Department of Public Administration, Olabisi Onabanjo University, \\ Ago-Iwoye, Nigeria \\ adeleke.adegbami@oouagoiwoye.edu.ng
}

\begin{abstract}
The study analysed the challenges facing the application of the federal character principle under Nigeria's federal system of government. This is with a view to understanding the limiting factors inhibiting the effective application of the federal character principle. The study utilised primary and secondary data. Primary data were collected through the administration of questionnaire and the conduct of in-depth interviews. The study population comprised 1,927 staff on Grade Levels 7-17, drawn randomly from six selected federal ministries. Questionnaire was administered to the respondents to elicit information on the challenges facing the application of the federal character principle in the Federal Civil Service. Out of 1,927 copies of questionnaire administered 1,548 (80\%) were duly completed and retrieved. Interviews were also conducted with six Permanent Secretaries (PS) of the selected ministries; five directors/deputy directors; six Commissioners of the Federal Character Commission (FCC) and the Secretary, Senate Committee on Federal Character and Inter-Governmental Affairs to complement information got from the use of questionnaire. Data collected were analysed using descriptive statistics and content analysis. The finding revealed the challenges facing the application of the principle included: forgery and falsification of the State of origin by applicants; political interference among the political officeholders; favouritism; manipulations by some staff in-charge of implementation; and failure of ministries to declare and advertise vacancies before recruitments. The study concluded that despite the good intentions of the federal character principle the challenges keep on inhibiting its successful implementation, and unless these challenges are removed, the principle may not achieve fully the purpose of its introduction.

Keywords: Federalism, Federal Character Principle, Ethnicity, Amalgamation, Colonialist and Poly-ethnic groups
\end{abstract}

\section{Introduction}

Nigeria, one of the most ethnically diverse countries of the world, is a product of British colonial hegemony. Nigeria is a collection of ethnic groups, which are heterogeneous in character. The nature of Nigeria's heterogeneity is manifest in terms of the multiplicity of languages, culture, and religion, socio-political, and economic developments (Agbodike, 2003). The 1914 amalgamation of the Southern and Northern Protectorates and the Lagos Colony by the British imperialist, brought together over 300 different ethnic groups with many languages and over 1,000 dialects in Nigeria (Okotoni, 2006).

However, those ethnic groups that were incongruously merged regardless of their differences reacted in different ways to the British engineered merger. For instance, some saw the merger as "involuntary and traumatic", while for others, it was "a forced 
brotherhood" (Ayoade, 2003). Therefore, since the 1914 odd merger of Nigeria's polyethnic entity, the nation has continued to witness incessant political mending, panel beating, and even attempted secession (Ayoade, 2003). It is for this reason that Suberu (2001), concluded that none of the nations in the world has ever had a 'more turbulent and tragic' system of governance than Nigeria.

Owing to its diversified nature, Nigeria adopted a federal system of government in 1954 based on the Littleton Constitution, and in order to curtail the problems of who gets what, where, and when, among the component units of Nigeria, the Federal Government then introduced the "Quota System" in 1954 (Federal Republic Nigeria, 2012). The use of the quota system was mainly concerned with the equalisation of inter-regional opportunities in education and federal appointments. Despite the introduction of the quota system in 1954 and its review in 1967, mutual mistrust, animosity, and diversity among various ethnic groups continued unabated until it degenerated into a civil war from 1967 to 1970. Prior to the civil war, Nigeria's First Republic which began with Nigeria's Independence in 1960 got truncated by the year 1966 as a result of a Military coup d'état which was seen by the Northerners as a sectional coup d'état at the behest of the Igbo ethnic groups within the Nigerian military. In quick retaliation, the Hausa/Fulani in the military carried out a counter-coup in July 1966 (Fasua, 2013).

The problem with Nigerian federalism is not unconnected with the way it emerged. Nigerian federation comes about through fiat of a foreign power; as Nigeria's federalism was imposed by the British (Ezeibe, 2009). Thus, Nigeria's federalism is not only complex but also hard to understand. It is not surprising that Nigeria in its 55 years of political sojourn has tried different forms of federalism. According to Ayoade (2009:iii): Nigerians have come to identify the first republic $1960-66$ as the golden age of federalism in Nigeria. From that Nigeria descended into command federalism under military rule which lasted with short intermissions from 1966-1999. Even thereafter, Nigeria operates a system in which the State Governments only exercise power and financial donations from the federal government. At best, the states of the Nigeria federation are mere political concessionaries. Nigeria in its bid to get it right as a unified federating nation had also attempted different conflict reduction mechanisms. These involve the use of "confederal, federal relationships and regional autonomy"; "differential allocation of government positions and resources to less advantaged groups”. Despite the adoption and application of these measures, no positive results were yielded. This consequently led to the Igbo attempted secession from Nigeria to form the Republic of Biafra; the attempt which snowballed into a civil war was unsuccessful because it was not mutually supported by other ethnic groups in Nigeria (cited in Eresia-Eke \& Eberiye, 2010).

After the civil war, the country's leadership took a number of policy measures to ameliorate ethnic rivalry, principal among which was the introduction of the Federal Character Principle entrenched in the 1979 and 1999 Constitution.

One of the areas in which the principle of federal character is being applied is the Federal Civil Service (FCS). The Federal Civil Service is a governmental institution that plays important role in ensuring that government policies and programmes result in tangible services for the citizens. That is, civil servants are indispensable in the smooth running of governmental activities as they are involved in designing, formulating, and implementing public policies, as well as discharging governmental functions and developmental programmes in an effective way (Ogunrotifa, 2012). Therefore, the 
composition of the Nigeria Federal Civil Service in line with the federal character principle is expected to cut across the nation for the purpose of equity and fairness. As laudable as the federal character principle is; especially in the distribution of the federal civil service employment, there are different problems militating against its successful implementation. It is against this background that the study analyses some of the challenges facing the application of the federal character principle in the Federal Civil Service of Nigeria with a view of recommending steps towards tackling the problems.

\section{Federal Character Principle: A Related Review of Literature}

The principle of federal character is not limited to Nigeria; it is given different names by different nations across the globe. For instance, it is referred to as "affirmative action", "positive action", "employment equity", or "benign discrimination" in places such as the United States of America, Canada, India, and South Africa (Drumbl \& Craig, 1997); and "representative bureaucracy" (Okotoni, 2003); "zoning formula"; "quota system"; or "federal character principle" (Adeosun, 2011) in Nigeria. According to McCrudden (1986), any policy measure or anti-discrimination law that could be termed as affirmative action must intend to affect the position of individuals whose prospects are impeded by unequal and unjustifiable treatment from other members of a particular group. That is, any affirmative action law should be able to guarantee equity, and far from bias and prejudice; such that a group of people must not be given preferential treatment over the other within a nation.

The available literature on the federal character principle further shows that scholars broadly view the concept from diverse perspectives and recognise it by different nomenclatures even though their views tilt along the same line. For instance, Maduagwu (1999) sees the federal character principle as a technical term for "ethnic policy", "ethnic engineering" or "ethnic management". Most of the scholars see the principle from the objectives which its original authors intended it to achieve, which is to inspire a sense of belonging and loyalty. Some other scholars argue that the federal character arose out of the need to correct the anomalies which emanated from the uneven distribution of natural and economic resources of the nation. Scholars such as Ezenwa (1987), Adamolekun, et al., (1991), Talib (2005), and Ojo (2009) note that the federal character is a veritable instrument for equal treatment of citizens, equal distribution of amenities, and a formula for fair distribution of a nation's political as well as economic powers. This is because where there is a fair distribution of amenities; there will be even development in the country and this would lessen rancour in the polity. Therefore, based on the views of these scholars, it could rightly be deduced that the federal character as a principle of state policy is a vehicle of political fairness in a poly-ethnic society, with regard to political and bureaucratic appointments, as well as the distribution of social amenities and economic facilities in the country.

The second chapter of the 1999 Constitution as amended entitled Fundamental Objectives and Directive Principles of State Policy enunciates clearly what the Federal Character Principle entails. The Constitution states in section 14, sub-section 3 that the composition of the Government of the Federation or any of its agencies and the conduct of its affairs shall be carried out in such a manner as to reflect the Federal Character of Nigeria and the need to promote national unity, and also to command national loyalty, thereby 
ensuring that there shall be no predominance of persons from a few States or from a few ethnic or other sectional groups in that government or any of its agencies.

The Federal Character Principle, according to this section of the Constitution, could be seen as a non-discriminatory principle, which aims at guarding against the monopolisation of governmental activities or the apparatus of government by a particular ethnic group or section of the country. Put differently, the intention behind the introduction of the federal character principle was to accommodate all the component units of the nation in all the governmental activities.

In a similar vein, Obiyan \& Akindele (2002) are of the opinion that the federal character principle is about putting into consideration the pluralist nature of the country when sharing administrative as well as political jobs and the economic resources of the country. According to them, this is pertinent in order to allow the conduct of public institutions affairs to reflect the country's diverse nature. Thus, when public institutions' affairs are made to reflect the pluralism or country's diversity, it will go a long way to encourage the citizens to have a sense of belonging.

However, contrary to the above section of the Constitution; and Obiyan \& Akindele positions, the irregularities and the protests that follow the posting, recruitment as well as the promotion exercise within the Nigeria Army in 2013 completely negated these objectives of the principle of federal character. It would be recalled in 2013 that a group of Army personnel, under the auspices of "Group for the Salvation of the Nigerian Army" petitioned the Presidency, the National Security Adviser, and the National Assembly alleging ethnicity and favouritism in the recruitment, promotion, and posting exercises in the Army under the then Chief of Army Staff (COAS), Lt. Gen. Azubuike Ihejirika. "Group for the Salvation of the Nigerian Army" has argued that the COAS has bastardised the practice of equity in the federal character principle in his attempt to "Igbonise" the Army as every posting, promotion, and recruitment was in favour of people of Igbo extraction to the detriment of other ethnic groups in Nigeria (Madugba \& Baba, 2013).

The federal character principle has been referred to as 'an instrument of eclectic redistribution of bureaucratic positions and industrial locations' (Ayoade, 2003). For Ayoade, the principle of federal character is essentially all about the re-allocation of political and economic powers. He equally sees the principle as a means of locating or positioning industries in Nigeria. On the other hand, Ezeibe (2009) posits that the federal character is all about building a nation of equal opportunities for the citizenry, where every individual would feel comfortable to participate in national affairs without let. Ezeibe's view is beyond economic distribution as he emphasises equal chances, a sense of belonging, opportunities as well as feelings of comfort and security for all diverse elements despite ethnic diversity. Up till now, Nigerians are still looking forward to that day of "equal opportunity for all; and individual comfortability". Ezeibe further sees the federal character as a "reaction as well as a system". This position is more realistic compared to his early position. For him, the principle "is a positive reaction" aims at amending and correcting anomalies in the conduct of public management in the years past; it is also a reaction against those anomalistic practices of the past - vis-à-vis "selfish and parochial consideration, which placed the self-interests above the national interest”.

In their study, Erero, et.al., (2004) note that federal character is "special consideration for disadvantaged groups in publicly funded opportunities”. The rationale behind this according to them is to "level the playing field as the groups preferred are often 
those that have been discriminated against in the past". To them, the federal character is for the selected few whom they tagged the "disadvantaged", and not for the generality of Nigerian citizens. However, the yardsticks for determining the "disadvantaged" and the "preferred groups" whose federal character is meant for are not stated by these scholars.

Arising from the above, the federal character principle is meant to address the critical issues or questions of equity and fairness; as well as to allow the under-represented groups of the nation's population opportunity or access to civil service jobs. This is with a view to discouraging ethnic rivalry, political instability, and mistrust in Nigeria, and that, lopsidedness in the appointments into the civil service jobs in the country will not continue. To date, this view seems a tall dream, considering the nature and practice of Nigeria's federalism; the pluralistic nature of the country, and complexities of people; as well as implementation challenges of the federal character principle.

\section{Methodology}

\section{Research Design}

The study adopted a survey as the research design. The choice of the research design becomes imperative in view of the fact that it is a research method in which a sample of the population is studied and the selection is made such that the sample is representative of the whole population. This type of design is suitable, because, the principle of federal character which this study is centred on has been in operation for some years which the study cannot change, but could only help in identifying its challenges and provides appropriate data on which to base a sound decision.

\section{Study Area and Study Population}

The study area is Abuja, the Federal Capital Territory (FCT) of Nigeria, which is the seat of government where all the Federal Ministries have their headquarters. The population for the study were staff of the Federal Ministries, comprising senior members of staff of the Ministries of Agriculture and Natural Resources, Information and Communications, Education and Youth Development, Finance and Economic Development, Labour and Productivity, and Science and Technology. These members of staff were drawn from Grade Levels 7-17. The selection of these categories of staff is justified on the grounds that they are always involved in the policy implementation at the level of the Ministries, while, the Ministries are selected because their roles are pertinent to the generality of the citizens of Nigeria.

\section{Sample Size and Sampling Technique}

A total number of 1,927 respondents were selected using a simple random sampling technique. They comprise the staff of the Ministries of Agriculture and Natural Resources (325); Information and Communications (205); Education and Youth Development (1,186); Finance and Economic Development (67); Labour and Productivity (113); and Science and Technology (31). This represents $10 \%$ of the total respondents. Each ministry had a sample proportional to its size within the study population. In each ministry, respondents were selected among the senior staff (Grade Levels 07-17) members. With this, every senior member of each of the selected ministries had an equal chance of being sampled. 


\section{Research Instruments}

The study utilised primary and secondary data. Primary data were collected through the use of questionnaire and conduct of in-depth interviews. A set of questionnaire was used to elicit information on the challenges facing the application of the federal character principle in the federal civil service of Nigeria from 1,927 senior staff of the selected ministries. Interviews were conducted with six Permanent Secretaries of the selected Ministries, five Director/Deputy Director of the Federal Character Commission (FCC), and six Federal Commissioners of the FCC representing the six geo-political zones. The interviewees were selected because of their managerial and administrative positions in the commission. The Secretary, Senate Committee on Federal Character and InterGovernmental Affairs was also interviewed because of his position in the national assembly. The information from the interviews further enriched the quality of data for the study.

Secondary data that were generated from 1979 and 1999 Nigerian Constitutions; relevant textbooks and journals; the Federal Character Commission's (FCC) official website and official publications such as, reports, Conference/Workshop proceedings and communiqué.

\section{Analysis and Discussions}

Table 1:The challenges facing the application of the principle in Nigeria

\begin{tabular}{|l|c|c|}
\hline Responses & Frequency* & Percentages \\
\hline Forgery and falsification by applicants & 1,457 & 15 \\
\hline Political interference & 1,384 & 14 \\
\hline Favouritism & 1,308 & 14 \\
\hline Manipulations by some staff in-charge of implementation & 1,222 & 13 \\
\hline Non-submission of annual and quarterly nominal rolls & 967 & 10 \\
\hline $\begin{array}{l}\text { Failure of Ministries to declare and advertise vacancies before } \\
\text { recruitments }\end{array}$ & 904 & 9 \\
\hline The non-co-operation of some Ministries & 865 & 9 \\
\hline $\begin{array}{l}\text { Non-compliance with the stipulated six-week period of advertisement } \\
\text { notices }\end{array}$ & 801 & 8 \\
\hline Disregard for the declaration of existing vacancies & 749 & 8 \\
\hline Total & $9,657 *$ & 100 \\
\hline
\end{tabular}

Source: Authors' Fieldwork

*The frequency exceeds 1,548 because respondents identified more than one challenge facing the application of the federal character principle

As touching the challenges facing the application of the federal character principle, as displayed in table 1 above, 1,457 (15\%) of the respondents identified forgery and falsification of information about the state of origin of applicants, as one of the major problems militating against the effective application of the principle. Forgery and falsification by applicants in form of claiming states other than their state of origin, do affect the implementation of the federal character principle. Many applicants who feel that the quotas for their states have been filled up do claim other states apart from their own in 
order to get appointments. Due to the high level of unemployment in the country, applicants, by hook or crook, go the extra mile in getting themselves appointed.

This is followed by $1,384(14 \%)$ respondents who asserted that political interference is also a challenge. On the issue of interference, governments and the managements are noted to be interfering in the appointments into the Federal Civil Service. Political interference had permeated all areas of national activities in Nigeria. All governmental activities are being politicised in a manner that there is nothing one can achieve or gain without playing politics. Getting appointments is based on who you know, and not on the certificate you possess. Politics in Nigeria is a type of politics where the winner takes all. Those at the helms of affairs, especially the political officeholders, use their offices to favour themselves and their political supporters. Those who belong to opposing sides in politics are tagged enemies, and consequently not allowed to benefit when sharing positions, including appointments into the Federal Civil Service. Similarly, the commissioners who are at the helms of affairs of the Federal Character Commission (FCC) are political appointees, who, oftentimes, dance to the tune of those that appoint them.

Also, 1,308 (14\%) of the respondents emphasised that favouritism was one of the major challenges. On many occasions, the directors in the ministries, the directors at the FCC and the commissioners of the FCC, and other political officeholders did share the available vacancies in the ministries among themselves. They made the process of recruitments to look perfect even when the available positions were being shared among them for the benefits of their kinsmen.

Another challenge facing the federal character principle as indicated by 1,222 (13\%) respondents was manipulations by some staff in-charge of implementation. Some staff that were in charge of the implementation of the federal character principle handled the exercise unethically; they did manipulate appointments and recruitments exercise to soothe their whims and caprices. There were some of them who did collect money from applicants before they could secure jobs. They had different prices for different jobs, depending on how juicy the jobs were.

This is followed by 967 (10\%) respondents who indicated "non-submission of annual and quarterly nominal rolls" as one of the challenges facing the application of the federal character principle. In order to aid the manipulation of the recruitment exercise, many directors as well as permanent secretaries were into the habit of hiding or refusing to submit annual and quarterly nominal rolls to the appropriate quarters. The implication of this is that the Federal Character Commission (FCC), which is in charge of regulating all appointments into FCS, may not be fully aware of the available vacancies in their ministry, hence, its inability to regulate the appointments appropriately.

Furthermore, 904 (9\%) of the respondents identified "failure of ministries to declare and advertise vacancies before recruitments" as a challenge facing the application of the federal character principle. Many of the ministries were fond of engaging in underground recruitments. Many times, recruitments would have been concluded before many applicants would know. Thus, by this, many qualified and eligible candidates were edged out of appointments.

Also, 865 respondents (9\%) attributed the challenge facing the federal character principle to "non-co-operation of some ministries". Non-cooperation on the part of some ministries was a great challenge to the application of the federal character principle. These 
ministries were fond of working against the Federal Character Commission (FCC), the regulatory body of the Federal Character Principle. On many occasions, these ministries would not submit their nominal rolls to the FCC. Besides, they would not advertise for the stipulated weeks before recruitments.

"Non-compliance with the stipulated six-week period of advertisement notices" was also a challenge to the effective application of the federal character principle as indicated by 801 (8\%) respondents. Federal ministries, most of the times, did not advertise the vacant post(s) in their ministries; even those who advertised did not allow the six weeks stipulated period to lapse. Thus, applicants were not aware of the available vacancies in the federal ministries, and therefore, could not apply. According to the respondents, the reason for not advertising the vacant post was for those in government and members of the management to share the available vacancies among their candidates. This act is detrimental to a successful application of the federal character principle.

Finally, 749 of the respondents (8\%) held the view that "disregard for the declaration of existing vacancies" constituted a challenge to the application of the federal character principle. The management of the ministries as well as their political allies did ignore the practice of sharing the available vacancies among the component states of the federation. Non-compliance with the federal character principle, as manifested in the disregard for the sharing of the available vacant post(s), thus, becomes a clog in the wheel of smooth application of the principle in the Federal Civil Service.

Findings through interviews conducted also supported the above. The interviewees identified basic challenges facing the application of the principle which included political interference and influence, favouritism and nepotism, manipulations by some staff in charge of implementation, forgery, and falsification of state of origin by applicants, and failure of Ministries to declare and advertise available vacancies before recruitment.

The interviewees also offer probable solutions to the above-listed challenges facing the application of the federal character principle to the Federal Civil Service. They (the interviewees) suggested that any aggrieved person as regards the application of the principle should petition the Federal Character Commission (FCC) and not the Court directly. However, if the commission failed or refused to act upon the petition, the petitioner could then institute legal action against the commission at any High Court of Justice. The petitioner could then seek an Order of Mandamus which would compel the commission to act on the petition without further delay.

This section is important in the sense that it reveals different limiting factors that hindered the smooth application of the federal character principle into the Federal Civil Service of Nigeria.

\section{Summary and Conclusion}

The federal character principle was introduced to redress the ethno-regional imbalance in Nigeria. One of the areas in which the principle has been applied is the Federal Civil Service (FCS). The principle was fairly implemented in the civil service as it had, to some extent, reduced the marginalisation of some ethnic groups. However, its implementation faces certain challenges, which include - Forgery and falsification of state of origin by applicants who were desperate to secure means of livelihood; political interference, a situation whereby, political appointees tamper with procedures of 
appointments in order to reward their faithful supporters; favouritism by the Management who helps some applicants to get appointment and promotion and Non-co-operation of some ministries with Federal Character Commission. These challenges have continued to inhibit the successful application of the principle and have to a considerable extent defeated the purpose for which the principle was introduced.

\section{Policy Recommendations}

Arising from the results and findings of the study, the following recommendations are made to help in the application of the federal character principle:

The study identified several challenges in the application of the federal character principle, which included - non-submission of quarterly and annual nominal rolls/nondeclaration of existing vacancies in the FCS. The Commission needs to work in collaboration with the Federal Civil Service Commission for regular update of Manpower Statistics in the various Ministries, agencies and parastatals in order to monitor their level of compliance. The commission will also need to maintain an updated website that is friendly and accessible to the public.

It was also revealed from the findings of the study that political interference and manipulations by some staff in-charge of implementation constitute a hindrance to the smooth application of the federal character principle. To address this, it is recommended that the federal government should introduce appropriate sanctions and penalties that will reduce political interference to the barest minimum. It is hoped that the recommendations will assist the Federal Character Commission (FCC) in fulfilling its mandate and remain relevant.

\section{References}

1. Agbodike, C. C. (2003). "Federal Character Principle and National Integration”. In Amuwo, K.; Agbaje, A.; Suberu, R. \& Herault, G. (eds.), Federalism and Political Restructuring in Nigeria. Ibadan: Spectrum Books Limited. pp. 177-188.

2. Ayoade, J. A. A. (2003). “The Federal Character Principle and the Search for National Integration”. In Amuwo, K.; Agbaje, A.; Suberu, R. \& Herault, G. (eds.), Federalism and Political Restructuring in Nigeria. Ibadan: Spectrum Books Limited. pp. 101-118.

3. Ayoade, J. A. A. (2009). “Foreword”. In Ojo, E. O., Mechanisms of National Integration in a MultiEthnic Federal State: The Nigerian Experience. Ibadan: John Archers (Publishers) Limited. pp. iii-iv.

4. $\quad$ Adamolekun, L. (1985). The Fall of the Second Republic. Ibadan: Spectrum Books Limited. 22-25.

5. Adamolekun, L., \& Ayo, S. B. (1989). The Evolution of the Nigerian Federal Administration System. Publius: Oxford Journal, 19(1), 157-176.

6. Adamolekun, L.; Erero, J. \& Oshionebo, B. (1991). Federal Character and Management of the Federal Civil Service and the Military. Publius: The Journal of Federalism, Oxford University Vol. 21, No. 4, 75-88.

7. Adeosun, A. B. (2011). Federal Character Principle and National Integration: A Critical Appraisal. International Journal of Politics and Good Governance, 2(2.4) Quarter IV, 1-13.

8. Bostan, I., Onofrei, M., Popescu, C., Lupu, D., \& Firtescu, B. (2018). Efficiency and Corruption in Local Counties: Evidence from Romania. Lex Localis, 16(2), 215-229, https://doi.org/10.4335/16.2.215229(2018)

9. Drumbl, M. A., \& Craig, D. R. (1997). Affirmative Action in Question: A Coherent Theory for Section 15(2). Review of Constitutional Studies, IV(1), 81-123. 
10. Erero, J., Oyedeji, B., \& Adesopo, A. (2004). “Implementing Affirmative Action in Nigeria’s Public Service: A case study”. In Mukherjee, R. \& Adamolekun, R. (eds). (2004). Implementing Affirmative Action in Public Services: Comparative Administrative Practice. The World Bank Technical Reports.

11. Eresia-Eke, A., \& Eberiye, S. S. (2010). The Rationality of Rotational Presidency: Multi-ethnicity Hampers Smooth Educational and Political Development. International Journal of Scientific Research in Education, 3(1), 73-81.

12. Ezeibe C. C. (2009). Federal Character Principle and Nationality Question in Nigeria. International Journal of Research in Arts and Social Sciences, 1 (Nsukka: Society for Research and Academic Excellence).

13. Ezenwa, U. (1987). Participatory Politics: The Socio-Economic Dimension, NIPSS Conference Proceeding.

14. Fasua, K. (2013). How the 1966 Counter-Coup was Planned. Retrieved May 27, 2012, from http://nationalmirroronline.net/new/how-the-1966-counter-coup-was-planned/

15. Federal Republic of Nigeria (1999). 1999 Constitution of the Federal Republic of Nigeria. Lagos: Federal Government Press.

16. Maduagwu, M. O. (1999). Nigeria’s Federal Character: Towards its Correct Constitutional Interpretation and Application. Current Jos Law Journal, 5(5), 65-85.

17. Madugba, A., \& Baba, J. (2013). Recruitment, Promotion Irregularities Rock Army. Retrieved May 14, 2013, from http://peoplesdailyng.com/recruitment-promotion-irregularities-rock-army/

18. Mc Crudden, C. (1986). Rethink Positive Action. Industrial Law Journal, 15(1), 219-243.

19. Obiyan, A. S., \& Akindele, S. T. (2002). The Federal Character Principle and Gender Representation. Nigeria Journal of Social Sciences, 6(4), 241-246.

20. Ogunrotifa, A. B. (2012). Federal Civil Service Reform in Nigeria: The Case of Democratic Centralism. Journal of Radix International Educational and Research Consortium, 1 (10), 1-45.

21. Ojo, E. O. (2009). The Federal Character Principle and the Search for National Integration. In Ojo, E. O. (ed.), Mechanisms of National Integration in a Multi-Ethnic Federal State: The Nigerian Experience. Ibadan: John Archers (Publishers) Limited. pp. 154-170.

22. Ojo, E. O. (2009). The Politics of Revenue Allocation and Resource Control in Nigeria: Implications for Federal Stability. Federal Governance, 7(1), 15-38, https://nbn-resolving.org/urn:nbn:de:0168-ssoar342778

23. Okotoni, O. (2003). Problems and Prospects of Nigerian Bureaucracy. Journal of Social Science, 7(3), 223-229.

24. Okotoni, O. (2006). Governance, Taxation, and Fiscal Policy in Nigeria. European Journal of Social Sciences, 2(2), 80-94.

25. Suberu, R. T. (2001). Federalism and Ethnic Conflict in Nigeria. Washington, D. C.: United States Institute of Peace Press.

26. Talib, A. (2005). “Federal Character and National Integration in Nigeria”. A Key Note Address Delivered to Course Participants at the National Institute for Policy and Strategic Studies, May 29th, 2005 at Kuru, Jos. Creative Commons Attribution - Non Commercial - No Derivatives 4.0 International License. 